\title{
AN UPDATED TAXONOMIC TREATMENT OF THE NATURAL HYBRIDS OF SARRACENIA L. (SARRACENIACEAE)
}

\author{
Ray Neyland • Jennifer Bushnell $•$ Department of Biology and Health Sciences $\bullet$ McNeese State \\ University・Lake Charles・LA $70609 \cdot$ USA •rneyland@mcneese.edu \\ Wannee TAngKham - Department of Agricultural Sciences • McNeese State University Lake \\ Charles $\bullet$ LA $70609 \cdot$ USA
}

Keywords: natural plant hybrids, Sarracenia, Sarracenia hybrids, Sarraceniaceae.

Abstract: Presently there exists confusion concerning the legitimacy and taxonomy of the named natural hybrids of Sarracenia. One reason for this confusion centers on the unsettled taxonomy of what may be called the $S$. rubra and the $S$. purpurea complexes. More specifically, hybrids derived from either or both of these two complexes are those for which the taxonomy is most unclear. Additionally, in some cases, collection data is scant or missing. Drawn from literature, collection records and field observations, a review of the named natural hybrids of Sarracenia is presented.

The five taxa included in the $S$. rubra complex are all conservatively treated in the NRCS, USDA (2014) website as subspecies of S. rubra Walter. However, Mellichamp and Case (2009) divided them into three separate species (two with subspecies). McPherson and Schnell (2011) placed S. alabamensis Case \& R.B. Case and S. jonesii Wherry as subspecies of $S$. rubra.

Mellichamp and Case's (2009) taxonomy is based largely on morphological and ecological factors. That is, the five members of the complex have broadly disjunct ranges that correlate with distinctive morphology. In that sense, it is a practical taxonomy although it has, as yet, no molecularbased systematic support. The question then becomes, how to treat the various hybrids from members of this complex? That is, should the members of the $S$. rubra complex be treated with some level of distinction or should they be treated as mere variants of a single species as much of the molecular evidence currently suggests?

For purposes of this paper, the five members of the $S$. rubra complex will be recognized as distinct in keeping with the taxonomy of Mellichamp and Case (2009). This decision is supported largely by practical considerations. Specifically, the recognizable morphology of each, correlated with their respective disjunct ranges supports their distinction based on traditional and ecological grounds.

In contrast, molecular evidence supports the distinction among three members of the $S$. purpurea complex (Neyland \& Merchant 2006, Ellison et al. 2012). Therefore, Mellichamp and Case's (2009) taxonomy that distinguishes $S$. purpurea L. subsp. venosa (Raf.) Wherry, S. purpurea subsp. purpurea and S. rosea Naczi is well grounded. It is noted, however, that McPherson and Schnell (2011) placed $S$. rosea as a variety of $S$. purpurea subsp. venosa.

It is the goal of this paper to provide a brief history and description of the named natural hybrids of Sarracenia. For purposes of this paper, this list consists of the 20 natural hybrids listed by Ellison et al. (2014). 
This study is derived from literature and herbaria searches. Additionally, information from field observations and new collections by the authors augment this study. A brief discussion of each recognized natural hybrid is listed in the following section. Specimens were collected using standard herbarium techniques. Taxonomy follows Mellichamp and Case (2009). Herbarium abbreviations follow Thiers (2014).

\section{Results and Discussion}

From this study, information on 20 named natural hybrids of Sarracenia is presented. This set of hybrids follows Ellison et al. (2014). The following alphabetic list includes the parent names, the type locality and type specimen for each. A brief description with historical and updated information is included.

\section{S. $\times$ ahlesii C.R.Bell \& F.W.Case}

Parents: (S. alata (Alph. Wood) Alph. Wood $\times$ S. alabamensis Case \& R.B.Case subsp. wherryi (D.E.Schnell) R.B.Case.

Type locality: Wet meadow, five miles southeast of Fruitdale, Washington County, AL, 1955. Holotype: Bell 1495 (NCU).

Mature leaves are erect and reddish. Sepals are green and suffused with maroon; the petals are yellow with maroon shading (Bell \& Case 1956). The holotype, which can be viewed online, consists of three flowers and no leaves. Bell and Case also tentatively identified a collection (Bell 1456a) from near Agricola, MS as $S . \times$ ahlesii. However, that specimen was later identified as $S . \times$ exornata and currently resides in the NCU herbarium. No other collections are known to the authors.

\section{S. $\times$ areolata Macfarlane}

Parents: $(S$. leucophylla Raf. $\times$ S. alata $)$.

Lectotype: Macfarlane s.n. (NCU).

Type locality: Theodore, Mobile County, AL, 1909.

Erect leaves are mostly green with darker veins and prominent white areoles on the operculum and peristome region. Sepals are mostly green and suffused with red; the petals are typically red. This hybrid is vegetatively similar to $S$. $\times$ moorei. Because the parents freely hybridize and their progeny easily backcross (Bell \& Case 1956), introgression produces a material amount of both leaf venation and flower color variation. Common within its small range, this hybrid has been collected in Jackson County, MS and Mobile County, AL. The lectotype can be viewed online.

\section{S. $\times$ casei Mellichamp}

Parents: (S. psittacina Michx. $\times$ S. alabamensis subsp. wherryi).

Type locality: Along US 45 just north of Deer Park, Washington County, AL, 1985.

Holotype: Mellichamp s.n. (UNCC).

The semi-decumbent leaves of this hybrid are thin textured and faintly hairy. Young leaves are somewhat bronze colored like those of its $S$. alabamensis subsp. wherryi parent (pers. obs.). The opercula are bonnet-shaped with translucent areoles derived from its $S$. psittacina parent. Flowers are small (Mellichamp 2008) with (presumably) red petals and sepals. No information with respect to fragrance is known. The senior author in Baldwin County, AL discovered a second population in 
2014. Because both of its parents bloom at about the same time in early May, this hybrid is readily produced. However, because of the restricted range of $S$. alabamensis subsp. wherryi this hybrid is rare. Its bonnet-shaped operculum is a character also evinced in $S . \times$ formosa, $S . \times$ gilpini and $S . \times$ wrigleyana. We note that among each of these hybrids with bonnet-shaped opercula, some individual leaves do not completely open along the suture lines. When this occurs, the leaves appear mostly closed like their $S$. psittacina parent. Both types of leaves can occur on the same individual plant.

\section{S. $\times$ catesbaei Elliott}

Parents: (S. flava L. $\times$ S. purpurea subsp. venosa).

Type locality: Along the margins of rivulets amidst the high sand hills of Chesterfield district in SC. Neotype: Macbride s.n. (CHARL).

With spreading, collar-shaped opercula, the semi-decumbent leaves are marked with red or purple. Each leaf typically exhibits a dark splotch of purple or red on the base of the operculum, a characteristic of its $S$. flava parent. Sepals and petals are red, a characteristic of its $S$. purpurea subsp. venosa parent. However, Bell (1952) noted that petals might have tints of yellow, a contribution from S. flava. Eliot and Stauffer (1951) provide a good image of this hybrid in its native habitat. Although plants have been collected over a large range that includes the Piedmont and Coastal Plain of GA, SC and NC, this hybrid is not common (Bell 1952; Mellichamp \& Case 2009). Its spreading operculum (not pinched in the middle), is a character also evinced in the vegetatively similar $S . \times$ chelsonii, $S . \times$ exornata, and $S . \times$ swaniana. Although the neotype collection sheet is not dated, the collection was made in the early 1800 s as it is referenced (as a species) by Elliot (1824). The actual specimen remains in good condition. Additional collections were located in the UNC, UNCC, and US herbaria.

\section{S. $\times$ charlesmoorei Mellichamp}

Parents: ( $S$. jonesii Wherry $\times S$. purpurea subsp. purpurea).

Type locality: Henderson County, NC, 2007.

Holotype: Mellichamp s.n. (UNCC).

Reddened or purplish leaves are semi-decumbent with undulated collar-shaped opercula that are pinched in the middle. Sepals and petals are red. This hybrid has been collected in three counties in the mountains of NC. Plants collected by Wherry in Henderson County were included in Bell's (1952) neotypification of $S$. $\times$ chelsonii. However, with the acceptance of $S$. jonesii as a distinct species, Mellichamp (2008) recognized $S . \times$ charlesmoorei as a distinct taxon and separate from $S . \times$ chelsonii. This hybrid is rare due to the loss of the montane bogs inhabited by its $S$. jonesii parent (Mellichamp 2008). Pinched in the middle, the opercula of this taxon are reminiscent of a traditional Dutch woman's cap. This shape is a character also evinced in the vegetatively similar $S$. $\times$ mitchelliana and $S$. $\times$ naczii.

\section{S. $\times$ chelsonii Veitch ex Masters}

Parents: (S. rubra subsp. rubra $\times$ S. purpurea subsp. venosa).

Type locality: Eastern shore of Scotland Lake, Scotland County, NC, 1947.

Neotype: Wellman s.n. (NCU).

The leaves of this hybrid are semi-decumbent with spreading, collar-shaped opercula. Sepals and petals are red. Attributed to a horticulturally engineered hybrid, the name $S$. $\times$ chelsonii first appeared in the literature in 1878. A natural specimen was first discovered in 1933 by Wherry in southeastern North Carolina (Bell 1949). The specimen collected in 1947 by Wellman from the 
western edge of the coastal plain in Scotland County, NC was designated as the neotype by Bell (1952). This collection consists of a single leaf. An additional specimen, also collected by Wellman at the type locality, consists of a single leaf and a single flower. Housed at NCU, these two are the only known specimens of this natural hybrid. The neotype may be viewed online.

\section{S. $\times$ courtii Veitch ex Wilson}

Parents: $($ S. purpurea $\times$ S. psittacina $)$.

Plants from this cross are known from horticulture. However, Sheridan and Scholl (1993) reported that they had observed a natural population of about ten individuals of what they called $S$. $\times$ courtii along a road embankment in Liberty County, FL in 1989. Because such a hybrid observed here would have $S$. rosea as its parent (not $S$. purpurea), these plants would be distinct from $S$. $\times$ courtii. Because no collection material apparently was made, this hybrid reported from Florida remains unconfirmed. The typically large temporal difference in the blooming times of the parents presumably would make such a hybrid, if it exists, quite rare.

\section{S. $\times$ excellens W.Bull.}

Parents: $($ S. leucophylla $\times$ S. minor $)$.

Type: None.

This hybrid was first named and described by Nicholson (1887). Commonly produced in horticulture, plants are erect with prominent areoles and somewhat arching opercula. The natural occurrence of this hybrid has been reported from the small area in the Florida Panhandle where the ranges of the two respective parents just barely overlap. However, our efforts to locate any natural collection material were unsuccessful.

\section{S. $\times$ exornata W.Bull.}

Parents: $($ S. alata $\times$ S. rosea $)$.

Type locality: Theodore, Mobile County, AL, (year unknown).

Neotype: Pennell s.n. (PENN).

Prominently marked with red or purple veins, each leaf is semi-decumbent with a spreading, collar-shaped operculum. Bell (1952) described the flowers as having red-brown sepals (sometimes tinged with green) and petals that are either red or rose with yellow margins. This hybrid has been collected in Mobile County, AL near Theodore and Spring Hill (Bell 1952). Bell also collected this hybrid in a bog five miles south of Agricola, MS in George County (Bell \& Case 1956). The USDA, NRCS (2014) distribution map indicates that this hybrid also occurs in Washington County, MS. In 2014, the senior author observed a population in Jackson County, MS. Several specimens are housed at the NCU herbarium. The neotype was located in the PH herbarium. It is noted that the PENN herbarium was incorporated into the PH herbarium in 1974.

S. $\times$ farnhamii Farnham nothosubsp. bellii (Mellichamp) Neyland, Bushnell \& Tangkham comb. et stat. nov.

Basionym: S. × bellii Mellichamp, Carniv. Pl. Newslett. 37: 114 (2008)

Note: The name $S . \times$ farnhamii was originally based on a hybrid between $S$. leucophylla (subsp. leucophylla) and $S$. rubra subsp. rubra. The plant Mellichamp (2008) described as $S . \times$ bellii (=S. leucophylla $\times$ S. rubra subsp. gulfensis) differs from $S . \times$ farnhamii in the strict sense at the rank of subspecies.

Parents: (S. leucophylla $\times$ S. rubra subsp. gulfensis). 
Type locality: West side of Hwy. 87 just north of Yellow River, Santa Rosa County, FL, 2008.

Holotype: Mellichamp s.n. (UNCC).

Similar to those of its S. leucophylla parent, this hybrid's leaves exhibit white areoles about the peristome and operculum. The opercula are wavy margined and longer than wide. The narrow operculum is a characteristic of its $S$. rubra subsp. gulfensis parent. Somewhat similar, the leaves of $S . \times$ farnhamii nothosubsp. bellii are consistently longer (to $42 \mathrm{~cm}$ ) than those of $S$. $\times$ readei (Mellichamp 2008). Although the authors know of no collections with flowers, the sepals and petals are likely red (as in both parents) and probably intermediate in size. This is apparently the only site (along power lines) where this rare hybrid has been collected. At this site, the senior author in 2014 confirmed that $S . \times$ farnhamii nothosubsp. bellii is still present.

\section{S. $\times$ formosa Veitch ex Masters}

Parents: $(S$. minor Walter $\times$ S. psittacina $)$.

Type locality: Moist pine barren, near Fitzgerald, Irwin County, GA, 1904.

Neotype: Harper 2211 (US).

Leaves of this hybrid are semi-decumbent with bonnet-shaped opercula and translucent areoles. Flowers are distinctive in that the sepals are primarily green and the petals are mostly red. The neotype may be viewed online. Originally named for a horticulturally derived plant in 1811, it was not until 1904 that a natural hybrid was collected. Since that time, additional collections have been made from southeastern GA. Collections also have been made in Nassau and Baker Counties in northeastern FL. Although previously not reported from Duval County, FL, the senior author observed this hybrid in bloom on the University of North Florida campus. These plants are not rare and are most easily detected in the field by their bicolor blooms.

\section{S. $\times$ gilpinii Bell \& Case}

Parents: (S. psittacina $\times$ S. rubra subsp. gulfensis).

Type locality: Savanna north of Yellow River and east of Florida highway 87; Santa Rosa County, FL, 1955.

Holotype: Bell 1523 (NCU).

This hybrid produces a rosette of semi-decumbent leaves; each bears a bonnet-shaped operculum with translucent areoles. Flowers were described by Bell and Case (1956) as small, faintly sweet-scented, with maroon sepals and petals. Attempts to locate the holotype (or any other naturally-collected specimens) were unsuccessful. A photograph, probably from the original collection, is included in the paper by Bell and Case (1956). According to Mellichamp (2008) this specimen was collected in the same bog with $S . \times$ farnhamii nothosubsp. bellii (see above). Although the senior author did manage to find $S$. $\times$ farnhamii nothosubsp. bellii there in 2014 (see above), he found no individuals of $S . \times$ gilpinii. Therefore, this hybrid would appear to be extremely rare or nonexistent in the wild. Assuming that the holotype is lost, then a neotype should be designated; however, we were unable to find any other herbarium collections. Designating the above mentioned photograph, as the neotype would be allowed under the article 9.6 of the ICBN (McNeil et al. 2011). Differences in flowering period between the two parents and the restricted range of $S$. rubra subsp. gulfensis are factors that contribute to the rarity of this hybrid.

\section{S. $\times$ harperi C.R.Bell}

Parents: (S. flava $\times$ S. minor $)$.

Type locality: Sandy bog in pine-barrens near Bloys, Bulloch County, GA, 1901.

Neotype: Harper 855 (US). 
Leaves are erect. Exhibiting a darkened splotch near its base, each operculum is revolute. Interestingly, the prominent translucent areoles of its $S$. minor parent are absent. Flowers unsurprisingly exhibit the green sepals and yellow petals of both its parents. Only a few collections from GA and $\mathrm{SC}$ were found during this study. Although the parents are sympatric over a large area of northern FL east of the Chattahoochee-Apalachicola River system, it is curious that there are no known collections from that state. The neotype can be viewed online.

\section{S. $\times$ mitchelliana W.Bull.}

Parents: (S. leucophylla $\times$ S. rosea $)$.

Type locality: Bog 2.5 miles west of Florida state line by U.S. 90, Baldwin County, AL, 1948.

Neotype: Bell 548 (NCU).

The leaves of this robust hybrid are semi-decumbent, each with a collar-shape operculum that is pinched in the middle. When young, white areoles about the operculum and peristome are evident. However, as the leaf ages, it becomes dark purple with the areoles becoming obscured. With its red sepals and pink petals, flowers are similar to its $S$. rosea parent. Flowers are nearly scentless (pers. obs.). Plants have been collected in Baldwin County AL, adjacent Escambia County, FL and from a disjunct population in Liberty County, FL. Bell (1952) stated that Harper (1918) found this plant in Walton County FL but we could not locate a collection from that county. The curious thing about this hybrid is that it is fairly common in Escambia County, FL and near its type locality in AL, but it seems to be rare or nonexistent in other areas where its parents are sympatric. The senior author observed plants at several locations in Escambia County, FL and some within the city limits of Pensacola in 2014. Considerable variation in leaf shape, color and size, probably due to introgression, is evident in plants that inhabit Splinter Hill Bog, Baldwin County, AL (pers. obs.).

\section{S. $\times$ moorei Moore ex Masters}

Parents: $($ S. flava $\times$ S. leucophylla).

Type locality: Sandy bog southeast of Americus, Sumter County, GA, 1901.

Neotype: Harper 1021 (US).

Marked with red veins, leaves are erect with white areoles about the peristome and operculum. Sepals are green and suffused with pale red; the petals are likewise pale red. This common hybrid's range extends from southern AL to northwestern FL and southwestern GA. Because its parents freely hybridize and introgression appears common, a myriad of morphological forms are produced. In 2013 and 2014, the senior author observed much variation in color and venation patterns among individuals of the Garcon Point peninsula, Santa Rosa County, FL. In 2013, this hybrid was collected for the first time in Escambia County, FL by the senior author in the type locality of $S$. $\times$ naczii. The neotype can be viewed online. Vegetatively similar, $S . \times$ areolata also produces a broad spectrum of variants.

\section{S. $\times$ naczii Mellichamp}

Parents: $($ S. flava $\times$ S. rosea $)$.

Type locality: South side of O.C. Phillips Rd., ca 3 miles east of Perdido River, Escambia County, FL, 2007.

Holotype: Mellichamp s.n. (UNCC).

The leaves of this robust hybrid are semi-decumbent, each with a collar-shape operculum that is pinched in the middle. Heavily marked with red or purple veins, each leaf bears a darkened splotch at the base of its peristome like that of its $S$. flava parent. Flowers are typically pale yellow with 
a pink cast (Mellichamp 2008). In 2014, the senior author observed plants in the type locality in Escambia County, FL and in a second location in Walton County, FL.

\section{S. $\times$ popei Masters}

Parents: (S. flava $\times$ S. rubra subsp. rubra).

Type locality: Carthage, Moore County, NC, 1926.

Neotype: Harriot s.n. (PH).

Erect leaves are light green with maroon markings. Large flowers exhibit maroon sepals with maroon petals that are edged with yellow (Bell 1952). An illustration of the flower and leaf is shown in Bell's (1952) paper. Although they are sympatric over a large range, mostly in the Carolinas, the two parent species produce few, if any, natural hybrids. Indeed, there are no other known natural hybrid collections between $S$. flava and any other member of the $S$. rubra complex. Neither the neotype nor any other collection of this taxon was located.

\section{$S . \times$ readei Bell}

Parents: (S. leucophylla $\times$ S. alabamensis subsp. wherryi).

Type locality: Deer Park, Washington County, AL. 1913.

Lectotype: Reade 5789 (PENN).

Prominently marked with the white areoles from its $S$. leucophylla parent, the leaves of this rare hybrid are slender and reddened like those of its other parent $S$. alabamensis subsp. wherryi. Flowers are maroon and intermediate in size (Bell \& Case 1956). The lectotype was located in the PH herbarium. Only two other collections known to the authors (Bell 1496 and Case P-63) were not located. Due to the restricted range of $S$. alabamensis subsp. wherryi, this hybrid is rare.

\section{S. $\times$ rehderi C.R.Bell}

Parents: $(S$. minor $\times$ S. rubra subsp. rubra $)$.

Type locality: Damp savannahs about 12 miles southwest of Shallottee, Brunswick County, NC, 1952.

Neotype: Rehder s.n. (NCU).

With reddish veins, erect leaves are green with white areoles about the peristome and operculum. Similar to those found in $S . \times$ harperi, the opercula are slightly revolute. Flowers are fragrant. Red sepals and petals are edged with yellow (Bell 1952). Bell reported that this hybrid was first collected by Wherry in 1923 in Candler County, GA but no herbarium specimen could be located. The neotype was collected in 1951 and consists only of leaves; however, a black and white photograph of the plant in flower is attached. An image of the neotype is available online. Plants also have been collected in Barnwell and Colleton Counties, SC.

\section{S. $\times$ swaniana Bull ex W.Robinson}

Parents: $(S$. minor $\times$ S. purpurea subsp. venosa $)$.

Type locality: From damp savanna about 12 miles southwest of Shallotte, Brunswick County, NC, 1952.

Neotype: Rehder s.n. (NCU).

Typical of other hybrids from the S. purpurea complex, leaves are semi-decumbent with spreading, collar-shaped opercula. A few translucent areoles about the base of the operculum are present (Bell 1952). Green sepals are suffused with red; petals are completely red. First mentioned as a horticulturally derived plant in 1887, it was not until Eliot and Stauffer's (1951) publication that a natu- 
ral hybrid was noted in the literature. Plants also have been collected in Bladen County, NC (Bell \& Case 1956). The few collections of this plant suggest its rarity. The neotype can be viewed online.

\section{S. $\times$ wrigleyana S.G.}

Parents: $(S$. leucophylla $\times$ S. psittacina $)$.

Type locality: Fowl River Road, south of Theodore, Mobile County, AL, 1954.

Neotype: Case P62 (NCU).

The leaves of this rare hybrid are semi-decumbent; each bears a bonnet-shaped operculum with translucent areoles. Like both its parents, the sepals and petals are red; however, the flowers are intermediate in size. This plant was first collected by Wherry near Fruitdale in Washington, County, AL in 1932 (Bell \& Case 1956); however, this collection could not be located. The neotype, which can be viewed online, originally consisted of leaves only. However, a flower was added later. The flower is from the original specimen that bloomed at the University of Michigan greenhouse in 1955. Bell and Case (1956) also listed a specimen from Escambia County, FL; however, that specimen could not be located. An additional specimen from Bay County, FL was located at FLAS 97441 (Beckner et al. 1506). Differences in flowering period between the two parents appear to be the major impediment in producing this hybrid.

\section{Conclusion}

From this study it is clear that some natural hybrids of Sarracenia are common and others are rare. Judging by the large numbers of horticulturally engineered hybrids, there does not appear to be any genetic incompatibility among the species of Sarracenia with respect to their ability to produce fertile hybrids. Indeed, hybrid swarms are common in the field (Ellison et al. 2014).

Natural hybrids occur in numbers when the two sympatric species are common and have at least some overlap in their respective periods of flowering. Examples include $S . \times$ areolata, $S . \times$ formosa, S. $\times$ mitchelliana, and $S . \times$ moorei.

Conversely, when these conditions are not met, natural hybrids are reduced or absent. For example, a temporal difference in floral period between parents fosters reproductive isolation. Sarracenia $\times$ wrigleyana provides a good example. Specifically, although $S$. leucophylla and S. psittacina occur sympatrically over a large range, hybrids seldom are produced. In situations where one of the parents occupies a small range, natural hybrids are likewise, restricted. For example, the rarity of both $S . \times$ casei and $S . \times$ farnhamii nothosubsp. bellii is due to the limited range of their respective parents S. alabamenis subsp. wherryi and $S$. rubra subsp. gulfensis. When floral periods between the two parents typically do not coincide and one of the parents has a restricted range, then the probability of progeny between the two is rare. Such is the case of $S$. $\times$ gilpinii.

In terms of their biological impact, rare Sarracenia hybrids are little more than curiosities. That is, their presence has minimal or no impact on the evolutionary trajectory of plants in their local group. However, in cases where hybrids are common, the evolutionary impact, at least with respect to the local group, can be substantial. Although there has been little or no molecular verification, it is likely, based on observable morphological variation, that introgression, resulting in hybrid swarms, occurs under these conditions. As mentioned previously, hybrid swarms appear to be present, at least in some local groups, where hybrids are common.

Acknowledgements: We thank the following for their assistance in locating requested herbarium specimens: Kent Perkins (FLAS); Layne Huiet (CHARL); Shanna Oberriter, Carol McCormick 
(NCU); Alina Freire-Fierro (PH). Jan Schlauer provided detailed advice on taxonomy. No special permits were required to visit the sites described in this paper.

\section{References}

Bell, C.R. 1949. A cytotaxonomic study of the Sarraceniaceae of North America. J. Elisha Mitchell Sci. Soc. 65: 137-166.

Bell, C.R. 1952. Natural hybrids in the genus Sarracenia L. History, distribution and taxonomy. J. Elisha Mitchell Sci. Soc. 68: 55-80.

Bell, C.R., and Case, F.W.1956. Natural hybrids in the genus Sarracenia. II Current notes on distribution. J. Elisha Mitchell Sci. Soc. 72: 142-152.

Case, F.W., and Case, R.B. 1976. The Sarracenia rubra complex. Rhodora 78: 270-325.

Elliott, S. 1824. A Sketch of the Botany of South-Carolina and Georgia. 2:11. Schenck, Charleston, SC.

Ellison, A.M., Butler, E.D., Hicks, E.J., Naczi, R.F.C., Calie, P.J., Bell, C.D., and Davis, C.C. 2012. Phylogeny and biogeography of the carnivorous plant family Sarraceniaceae. PLoS ONE 7(6): e39291.

Ellison, A.M., Davis, C.C., Calie, P.J., and Naczi, R.F.C. 2014. Pitcher plants (Sarracenia) provide a $21^{\text {st }}$-century perspective on infraspecific ranks and interspecific hybrids: a modest proposal* for appropriate recognition and usage. Systematic Botany 39(3): 939-949.

Eliot, R., and Stauffer. M. 1951. June in savanna land. Wild Flower 27: 32-41.

Harper, R.M. 1918. The American Pitcher plants. The Elisha Mitchell Science Society. 34: 110-135.

McNeil. J., Barrie, F.R., Buck,W.R., Demoulin, V., Greuter, W., Hawksworth, D.L., Herendeen, P.S., Knapp, S., Marhold, K., Prado, J., Prud'homme van Reine, W.F., Smith, G.F., Wiersema, J.H. eds. 2011. International Code of Nomenclature for algae, fungi, and plants (Melbourne Code), Adopted by the Eighteenth International Botanical Congress, Melbourne Australia, July 2011 (electronic ed.). Bratislava, International Association for Plant Taxonomy.

McPherson, S., and Schnell, D.E. 2011. Sarraceniaceae of North America. Dorset: Redfern Natural History Productions.

Mellichamp, T.L. 2008. New names for natural hybrids in Sarracenia. Carniv. P1. Newslett. 37: 112-117.

Mellichamp, T.L., and Case, F.W. 2009. Sarraceniaceae. In: Flora of North America Editorial Committee eds. Flora of North America North of Mexico Vol. 8. Magnoliophyta: Paeoniaceae to Ericaceae. Oxford University Press, New York and Oxford. 348-363.

Neyland R., and Merchant, M. 2006. Systematic relationships of Sarraceniaceae inferred from nuclear ribosomal DNA sequences. Madroño 53: 223-232.

Sheridan, P., and Scholl, B. 1993. Noteworthy Sarracenia collections. Carniv. Pl. Newslett. 22: 5861.

Thiers, B. 2014. Index Herbariorum: A global directory of public herbaria and associated staff. New York Botanical Garden's Virtual Herbarium. http://sweetgum.nybg.org/ih/.

USDA, NRCS. 2014. The PLANTS Database National Plant Data Team, Greensboro, NC 274014901 USA. http://plants.usda.gov/java/. Accessed 11 Sep 2013. 